\title{
Approaches to MATLAB Experimental Course
}

\author{
Xinwu Chen, Shuaibin Lian, Wenxia Huang, Peng Wang, Qiuju Sun, Lijuan Zhong \\ School of Physics and Electronic Engineering, Xinyang Normal University, Xinyang, China \\ Email: chenxinwu@126.com
}

How to cite this paper: Chen, X.W., Lian, S.B., Huang, W.X., Wang, P., Sun, Q.J. and Zhong, L.J. (2016) Approaches to MATLAB Experimental Course. Open Access Library Journal, 3: e2808.

http://dx.doi.org/10.4236/oalib.1102808

Received: August 8, 2016

Accepted: September 6, 2016

Published: September 9, 2016

Copyright $\odot 2016$ by authors and Open Access Library Inc.

This work is licensed under the Creative Commons Attribution International License (CC BY 4.0).

http://creativecommons.org/licenses/by/4.0/

\section{(c) (i) Open Access}

\begin{abstract}
MATLAB programming is currently a widely established course for science and engineering specialty, different universities differ a lot in making the standard of this experimental course, however, the existing common problem is the weak disconnect between the contents and special training. To overcome the problem of disconnect between study and application of MATLAB, Schedule and contents of this course were discussed, and design experiment was enhanced. This revision takes not only into account for the connecting of contents but also fusion with corresponding frontier information field. Students enjoy the experiment, a preliminary understanding of the application situation of MATLAB programming language, and the educational quality can be improved.
\end{abstract}

\section{Subject Areas}

Education

\section{Keywords}

MATLAB Experiment Course, Design-Featured Experiment, Digital Image

Processing, Gene Sequence Analysis

\section{Background}

In the middle of 1970s, the first version of MATLAB was demonstrated by Professor Cleve Moler in FORTRAN language. Cooperated by two other colleagues, they rewrite MATLAB Kernel in C programming language, established Mathworks Company and made the software a trademark. Now, 40 years later, the software has become the world-famous application software for mathematical computing, graph and image display, current simulation. It can be used for front-end idea verification toolbox for integrated development and circuit system design. As for digital image and speech signal processing area, MATLAB can be used for application software to implement real-time information processing. In China, many universities established MATALB programming 
course for training scientist and engineers, and in the course, some experiments were arranged for students practicing. As an average university, School of Physics and Electronic engineering Xinyang Normal University, also teach students MATLAB programming language for two majors, namely, electronic information engineering and electronic science \& technology. The course has been carried out for seven years.

During recent years, major trans-conformation is rising to an unprecedented height. To improve the quality of our students, we carried out a series of actions. In 2009, our university cooperated with Xinyang city government built the service platform of common electromechanical technology, in 2010,our school cooperated with Shanghai Enlearn Electronic Company limited of Science and Technology built Enlearn innovative workroom, in 2011, our university cooperated by Shenzhen Jilan Company limited of Science and Technology built develop center and training base to join the research and development group, in 2012, based on electronic technology innovation group of our university and platform of common electromechanical technology, combined with the resources of teaching, electronic technology practical innovation base was built, and used for extracurricular practice base of two majors including electronic science \& technology and electronic information engineering. About $350 \mathrm{~K} \$$ was investment in the first period, and $340 \mathrm{~K} \$$ was supported by central finance, $190 \mathrm{~K} \$$ by our university, $15 \mathrm{~K} \$$ by local enterprises. Up to now, the total value of equipments in our base is above $1 \mathrm{M} \$$. The main parts of our base includes electronic product design laboratory, electric and electronic training laboratory, $\mathrm{PCB}$ fabrication laboratory, digital control process laboratory, electronic product test center, student innovation management center, etc.

Based on the several platforms above, to improve the teaching quality and students abilities of software and hardware development, refer the literature about how to teach students to deeply understand the programming skills [1]-[7], the document provided by Mathworks Company titled "MATLAB getting started guide 2011B [8]" was selected as textbook, and contents from some other textbooks was fused [9]-[12].

\section{Start Time}

In many Chinese universities, MATLAB programming language starts up at the forth term or even later time. After a careful consideration and discussion, we decided to start up the course at the first semester. A different opinion occurred at the discussing meeting because our students haven't study linear algebra and MATLAB is based on matrix theory. According to the view, we should start up the course at fourth or even later semester due to linear algebra start up at third semester. For convenience, we call the former approach as first semester schedule, FirSS for abbreviation, and the latter one fourth semester schedule, FouSS for abbreviation. Now we list advantages and disadvantages for the two schemes.

\subsection{Advantages for FirSS}

If we start up MATLAB programming at first semester, the advantages include the fol- 
lowing:

1) We can use MATLAB programming and Simulink in many courses such as circuit analysis, signals and systems, principles of communication, principles of automatic control theory, and other following courses. On the contrary, If we start up the MATLAB programming language at forth semester, we can't use MATLAB as a tool for many other courses such as signals and systems. It is well known that MATLAB is widely used in the first professional course named circuit analysis which is started up in the second semester or even in the first semester (according to our teaching schedule, circuit analysis is started up at second semester).

2) The basic techniques and knowledge of programming language can be extended to the next semester course called $C$ programming language.

3) Students can study MATLAB programming and Simulink further step by step, and take part in some research group existing in our university, and some competes from all over the world including mathematical modeling.

4) According to our teaching schedule, another computer course named fundaments of computer will be carried out in first semester, FirSS may help student understanding programming from different views.

\subsection{Disadvantages for FirSS}

If we start up MATLAB programming at first semester, the disadvantages include the following:

1) The absent matrix knowledge may cause hard degree of this course a little higher; hence the contents may puzzle a little more students.

2) The lack of basic skills and understanding at computer may prevent students from accepting some important concepts.

\section{Experiment Contents}

The existing textbooks always demonstrate how to finish some certain tasks with completed programs of reference. To avoid plagiarizes we designed a set of topics as the assignments of students. Each student has his or her unique assignment according to the student ID number and the picture of his or her own. Furthermore, we involved some interesting or frontier mattered contents. Every student can finish the assignments by himself or herself. To communicate with other MATLAB teachers, we list the contents in Table 1. We give an example for reference whose serial number is 0421035302 in Section 4.

\section{Design Example}

Demand: Cut your own image into 16 small pieces, and randomly put them together as shown in Figure 1. Here, we give a reference code as follows.

im = imread('barbara.png');

subplot (121); imshow (im,[]); imp = cell $(4,4)$;

for $\mathrm{m}=1: 4$ 


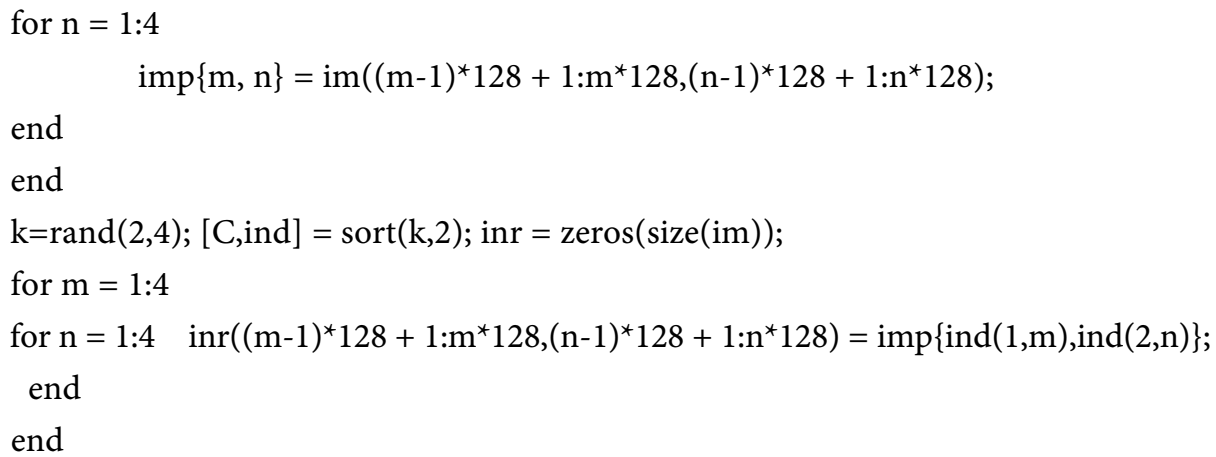

Table 1. MATLAB experimental contents.

\begin{tabular}{|c|c|c|c|c|c|}
\hline $\begin{array}{c}\text { Serial } \\
\text { Number }\end{array}$ & Experimental Name & Main content description & $\begin{array}{l}\text { Class } \\
\text { Time }\end{array}$ & $\begin{array}{l}\text { Experimental } \\
\text { Type }\end{array}$ & $\begin{array}{l}\text { Default } \\
\text { /Optional }\end{array}$ \\
\hline 0421035301 & $\begin{array}{l}\text { MATLAB Basic } \\
\text { Operation }\end{array}$ & $\begin{array}{l}\text { Generate a random matrix, implement } \\
\text { conventional operation }\end{array}$ & 3 & Verification & Default \\
\hline 0421035302 & $\begin{array}{l}\text { Output Student image } \\
\text { Number Circulation }\end{array}$ & $\begin{array}{l}\text { Using loop to display your image by } \\
\text { slices }\end{array}$ & 3 & Design & Default \\
\hline 0421035303 & Image processing & $\begin{array}{l}\text { Add } 1000 \text { salt and peppers noise to your } \\
\text { own image and remove it using three } \\
\text { kinds of mask method }\end{array}$ & 3 & Design & Default \\
\hline 0421035304 & Plot & Plot 2D function curve and 3D surface & 3 & Design & Default \\
\hline 0421035305 & Circuit analysis & $\begin{array}{l}\text { For a given circuit, using KCL and KVL, } \\
\text { establish circuit equation, design the } \\
\text { code }\end{array}$ & 3 & Design & Default \\
\hline 0421035306 & GUI & $\begin{array}{l}\text { A GUI interface on one's own } \\
\text { interesting }\end{array}$ & 3 & Design & Default \\
\hline 0421035307 & $\begin{array}{l}\text { Speech signal } \\
\text { processing }\end{array}$ & $\begin{array}{c}\text { Record one's own sound for about } 10 \\
\text { seconds, analyze frequency } \\
\text { characteristics }\end{array}$ & 3 & Design & Optional \\
\hline 0421035308 & $\begin{array}{l}\text { Gene sequence } \\
\text { analysis }\end{array}$ & $\begin{array}{l}\text { Generate a gene sequence by random } \\
\text { function, simulate gene sequencing }\end{array}$ & 3 & Design & Optional \\
\hline
\end{tabular}
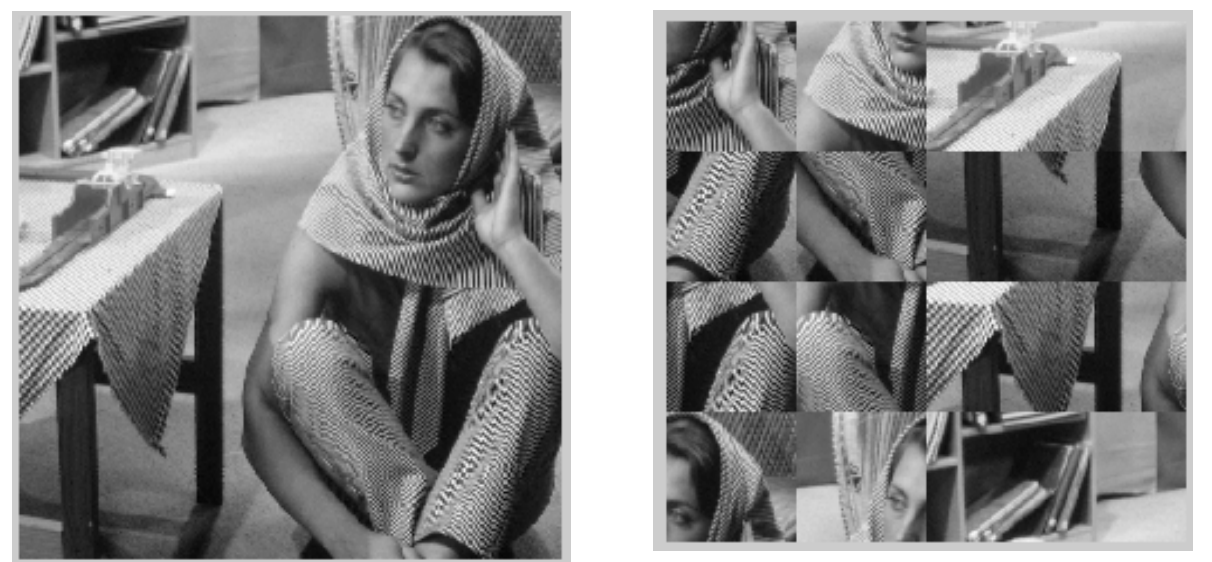

Figure 1. Personal assignment example. 


\section{Summary}

In order to embody the application function of MATLAB, we established the course at first semester. To make the course interesting in study process, we emphasized the ratio of design experiment and made the assignments unique for each student. It should be pointed out that MATLAB is only one course in the whole training plan, it must be cooperated with other courses to make better effects. We arrange digital circuits at second semester and open Verilog HDL at the same time. Combining MATLAB and Verilog HDL can make good use of our several practical training platforms, and laying good fundamental for future courses.

\section{Acknowledgements}

This paper was supported by key scientific research project of education department of Henan Province (No. 12A510020).

\section{References}

[1] Jovanovic Dolecek, G. (2012) MATLAB-Based Program for Teaching Autocorrelation Function and Noise Concepts. IEEE Transactions on Education, 55, 349-356. http://dx.doi.org/10.1109/TE.2011.2176736

[2] Torolu, G. and Sevgi, L. (2014) Finite-Difference Time-Domain (FDTD) Matlab Codes for First- and Second-Order em Differential Equations [Testing Ourselves]. IEEE Antennas and Propagation Magazine, 56, 221-239. http://dx.doi.org/10.1109/MAP.2014.6837093

[3] Liu, H., Xiao, W., Zhao, H. and Sun, F. (2014) Learning and Understanding System Stability Using Illustrative Dynamic Texture Examples. IEEE Transactions on Education, 57, 4-11. http://dx.doi.org/10.1109/TE.2013.2262684

[4] Molaro, M.C. and Braatz, R.D. (2013) Speeding Up Matlab Programs by Orders of Magnitude [Focus on Education]. IEEE Control Systems, 33, 135-163. http://dx.doi.org/10.1109/MCS.2013.2279486

[5] Sevgi, L. (2012) Teaching EM Modeling and Simulation as a Graduate-Level Course. IEEE Antennas and Propagation Magazine, 54, 261-269. http://dx.doi.org/10.1109/MAP.2012.6348176

[6] Gil-Sánchez, L., Masot, R. and Alcañiz, M. (2015) Teaching Electronics to Aeronautical Engineering Students by Developing Projects. IEEE Revista Iberoamericana de Tecnologias del Aprendizaje, 10, 282-289.

[7] Enikov, T. and Campa, G. (2012) Mechatronic Aeropendulum: Demonstration of Linear and Nonlinear Feedback Control Principles With MATLAB/Simulink Real-Time Windows Target. IEEE Transactions on Education, 55, 538-545. http://dx.doi.org/10.1109/TE.2012.2195496

[8] Mathworks. Matlab getting started guide R2011b. http://www.mathworks.com

[9] Choi, K. and Liu, H.P. (2016) Problem-Based Learning in Communication Systems Using MATLAB and Simulink. Wiley-IEEE Press, New Jersey.

[10] Hahn, B.D. and Valentine, D.T. (2007) Essential MATLAB ${ }^{\circledR}$ for Engineers and Scientists. 3rd Edition, Elsevier Ltd., Amsterdam.

[11] Parm III, W.J. (2011) Introduction to MATLAB ${ }^{\circledR}$ for Engineers. 3rd Edition, McGraw-Hill, New York. 
[12] Chapman, S.J. (2012) MATLAB Programming with Applications for Engineers. CLEngineering, Selangor.

Submit or recommend next manuscript to OALib Journal and we will provide best service for you:

- Publication frequency: Monthly

- 9 subject areas of science, technology and medicine

- Fair and rigorous peer-review system

- Fast publication process

- Article promotion in various social networking sites (LinkedIn, Facebook, Twitter, etc.)

- Maximum dissemination of your research work

Submit Your Paper Online: Click Here to Submit

Contact Us: service@oalib.com 